\title{
Analisis Kebutuhan Pelatihan Karyawan Divisi Perbengkelan di Perusahaan Komponen Otomotif Bahan Karet
}

\author{
Training Needs Analysis of Workshop Employee in Automotive Component Company of Rubber \\ Material
}

\author{
Aulia Rizqi Nur Abidi ${ }^{1 *}$, Nurmala K. Panjaitan ${ }^{1 \sharp}$, dan Joko Affandi ${ }^{1 *}$ \\ ${ }^{1}$ Magister Manajemen dan Bisnis, Sekolah Pascasarjana Institut Pertanian Bogor \\ *Gedung MB IPB, Jalan Raya Pajajaran, Bogor, 16151
}

\begin{abstract}
ABSTRAK
Perusahaan OBK merupakan perusahaan akuisisi tahun 2013. Pengakuisisian ini menyebabkan adanya perubahan jajaran manajerial perusahaan yang berpengaruh terhadap kebijakan-kebijakan baru yang diterapkan pada perusahaan. Salah satu kebijakan yang sedang dilakukan adalah pengembangan karyawan sebagai upaya peningkatan kinerja perusahaan. Penelitian ini bertujuan menganalisis persepsi karyawan divisi perbengkelan terhadap pelatihan yang sudah pernah dilakukan dan persepsi peningkatan kinerja setelah mengikuti pelatihan, menganalisis hubungan persepsi responden pelatihan dengan persepsi kinerja setelah mengikuti pelatihan, menyusun kebutuhan pelatihan karyawan berdasarkan kompetensi yang dibutuhkan perusahaan. Data diolah dengan uji rataan skor untuk persepsi, uji korelasi rank pearson untuk korelasi dan Training Needs Assessment Tool (TNA-T). Dari hasil penelitian, persepsi karyawan subdivisi produksi dan subdivisi PPIC memberikan penilaian rataan puas terhadap pelatihan yang pernah diikuti, sedangkan pada subdivisi $Q C$ dan maintenance menilai dengan persepsi rataan cukup puas. Persepsi peningkatan kinerja setelah pelatihan untuk subdivisi produksi, QC, PPIC rataan meningkat sedangkan pada subdivisi maintenance rataan sedang. Hubungan pelatihan yang sudah diikuti dengan peningkatan kinerja pada subdivisi produksi, PPIC, QC dan maintenance memiliki arah positif artinya semakin tinggi persepsi pelatihan maka semakin tinggi persepsi peningkatan kinerja. Pada subdivisi produksi, subdivisi PPIC dan subdivisi QC memiliki kategori hubungan kuat dan nyata pelatihan dengan peningkatan kinerja. Persepsi responden pada subdivisi tersebut rataan memberikan penilaian tinggi untuk pelatihan dan peningkatan kinerja sedangkan pada subdivisi maintenance memiliki hubungan rendah dan tidak nyata pelatihan dengan kinerja. Hubungan rendah diasumsikan terjadi karena penilaian responden cenderung beragam terhadap pelatihan. TNAT menjelaskan keseluruhan responden membutuhkan pelatihan namun tidak bersifat mendesak.
\end{abstract}

Kata kunci: analisis kebutuhan, karyawan, kinerja, pelatihan, persepsi

\begin{abstract}
OBK is the company's acquisition in 2013. This acquisition led to a change in the managerial rank that influence new policies were implemented company. New policy of employee development as an effort to increase the performance of the company. This study aimed to analyze the perception of Workshop division employee of accomplished trainings at OBK Company and their improved performance after the training. This study analyze the relationship between the respondents perceptions towards accomplished training activities and the perceptions towards performance after the training. The perception data were processed using an average test score, the correlation using Pearson's rank test and training Need Assessment Tool (TNA-T) to analyze the employee training needed. The results showed that the perception of production and PPIC subdivisions are satisfied with the training organized by the company and the perception of Maintenance and QC subdivision are quite satisfied. Perception on the improved performance of Production, QC and PPIC subdivisions after the training is increased on the
\end{abstract}

\footnotetext{
*) Korespondensi:

Gedung MB IPB, Jalan Raya Pajajaran, Bogor, 16151
} 
average. Meanwhile the performance of Maintenance subdivision is enough. The relationship between the variables of training and improved performance in Production, PPIC, QC and Maintenance subdivision has a positive direction. This shows that the higher the perception of the training, the higher the perception of improved performance. A strong and significant relationship between training and improved performance are on Production, QC and PPIC subdivisions. Respondent perceptions on these subdivisions are high on the average. On the Maintenance subdivision, the relationship is low and not significant between training and performance. Low relationship is assumed to occur because the assessments of respondents tend to vary on the training variable. The result of TNA tools that training is required by all respondents but not urgent.

Key words: employee, perceptions , performance, training needs assessment, training

\section{PENDAHULUAN}

The Boston Consulting Group dalam laporan berjudul "Growing pains, lasting advantage: Tackling indonesia's talent challenges" mengemukakan bahwa negara Indonesia kekurangan sumber daya manusia (SDM) sebagai tenaga kerja bermutu. BCG (2013) memprediksikan bahwa di tahun 2020, kesenjangan permintaan dan penawaran tenaga kerja akan semakin tinggi (56\%). Perusahaanperusahaan besar di Indonesia hanya bisa mengisi sekitar setengah kebutuhan pekerja tingkat pemula dengan kandidat yang benar-benar bermutu. Di tingkat senior, dari segi jumlah, tingkat kekurangan diperkirakan akan lebih rendah tetapi banyak kandidat kurang memiliki pengalaman global dan kemampuan memimpin yang dibutuhkan untuk meraih kesuksesan.

BCG menyarankan tujuh pendekatan yang dapat digunakan untuk perencanaan tenaga kerja, yaitu, rekrutmen, pelatihan, pengembangan karir, manajemen kinerja, merek perusahaan, keahlian pekerja, dan sistem meritokrasi. Pelatihan berkelanjutan dan terprogram memang membutuhkan biaya cukup besar, baik yang dilakukan secara internal maupun bekerjasama dengan lembaga pelatihan.

Pelatihan berkelanjutan dan terprogram dibutuhkan agar perusahaan dapat menekan pengeluaran biaya yang lebih besar lagi untuk menanggung biaya kerusakan, kesalahan atau kecelakaan akibat kerja karyawan. Pelatihan dibutuhkan bagi industri berkembang untuk bersaing di era perekonomian yang sedang berkembang pesat (McClelland, 2002). Industri berkembang di Indonesia membutuhkan pelatihan untuk meningkatkan kinerja karyawan agar mampu bersaing di era globalisasi. Salah satu industri yang sedang berkembang dengan sangat pesat di Indonesia adalah industri otomotif.
Salah satu pemain utama industri komponen otomotif adalah PT Astra Otopart. Dalam usaha memenuhi kebutuhan jumlah komponen otomotif sesuai peningkatan permintaan penjualan kendaraan bermotor setiap tahunnya, PT Astra Otopart bekerjasama dengan perusahaan-perusahaan lain dalam pengadaan komponen tersebut. Salah satu perusahaan member of Astra Otopart dengan produksi komponen otomotif bahan karet adalah PT IKP.

PT IKP memproduksi rubber molded parts, rubber extruded parts/hoses, dan rubber vibration insulation parts (cushion/mounting). Peningkatan permintaan komponen otomotif di Indonesia setiap tahunnya menyebabkan perusahaan ini bekerjasama dengan perusahaan-perusahan lain sebagai vendor pengadaan komponen otomotif berbahan baku karet. Salah satu vendor tersebut adalah perusahaan OBK.

Perusahaan OBK didirikan pada tahun 2008. Perusahaan ini memegang $30 \%$ dari $50 \%$ produksi komponen otomotif bahan baku karet di PT IKP dari lima vendor lainnya dan 50\% lainnya diproduksi oleh PT IKP sendiri. Perusahaan OBK diakuisisi oleh PT IKP pada tahun 2013. Pengakuisisian ini menyebabkan adanya perubahan jajaran manajerial perusahaan yang secara langsung berpengaruh terhadap kebijakan-kebijakan baru yang diterapkan pada perusahaan. Salah satu kebijakan yang sedang dilakukan adalah pengembangan karyawan dengan pelatihan sebagai upaya peningkatan kinerja perusahaan.

Tujuan penelitian ini menganalisis persepsi karyawan perusahaan OBK mengenai pelatihan yang pernah diikuti dan peningkatan kinerja setelah pelatihan, menganalisis hubungan antara persepsi pelatihan yang sudah diikuti dengan peningkatan kinerja karyawan perusahaan OBK, menyusun kebutuhan pelatihan menurut kondisi karyawan perusahaan OBK berdasarkan kompetensinya. 


\section{METODE PENELITIAN}

Penelitian ini dilakukan di industri komponen otomotif berbahan baku karet, yaitu Perusahaan OBK. Pengumpulan data dilakukan pada bulan Mei hingga Agustus 2016.

\section{Pengolahan dan Analisis Data}

Data primer yang diperoleh dari hasil penelitian ini merupakan data kualitatif yang tidak memiliki nilai nominal, sehingga dibutuhkan proses untuk mengubah data tersebut menjadi data kuantitatif. Proses tersebut dilakukan dengan skala semantic differentials (perbedaan semantik). Penilaian dengan skala semantic differentials bisa lebih mendalam, karena skor dari skala tersebut dianggap mempunyai tingkat interval sehingga dapat dihitung rataan dan simpangan bakunya (Sedarmayanti dan Hidayat 2002). Menurut Sekaran (2010), skala semantic differentials digunakan untuk mengukur persepsi seseorang atau sekelompok orang mengenai fenomena sosial. Pada penelitian ini responden diminta untuk mengisi ruang semantic tersedia untuk merefleksikan persepsi responden terhadap subyek, obyek atau kejadian yang terdapat pada kuesioner.

\section{Analisis statistik deskriptif}

Analisis statistik deskritif digunakan untuk melihat penilaian responden terhadap pernyataan dalam kuesioner menggunakan analisis rataan skor. Teknik rataan skor digunakan untuk mengetahui persepsi/sikap/tanggapan karyawan mengenai pelatihan dan kinerja dari pernyataanpernyataan yang diberikan kepada responden melalui kuesioner. Analisis persepsi ini bertujuan identifikasi persepsi responden terhadap program pelatihan karyawan yang telah dilakukan oleh Perusahaan OBK. Langkah-langkah yang dilakukan dalam analisis rataan skor adalah:

a. Pengelompokan jawaban

Kuesioner diberikan dalam bentuk pertanyaan-pertanyaan. Setiap pertanyaan dalam kuesioner tersebut diukur dengan skala semantic diferentials. Ajani (2013), Lee (2015) dan Pizam (2016) menggunakan skala semantik dengan lima penilaian dengan nilai bobot tertentu. Angka 1 menunjukkan adanya arah persepsi yang tidak disukai dengan intensitas (nilai semakin negatif), sedangkan angka 5 menunjukkan arah persepsi yang disukai dengan intensitas tinggi (nilai semakin positif). b. Perhitungan skor dan rataan skor

Perhitungan skor setiap komponen menggunakan rumus berikut:

Skor $=\Sigma($ Frekuensi Jawaban $\times$ Bobot Skala $)$

$$
\text { Nilai rataan skor }=\frac{\text { Total Skor }}{\text { Jumlah responden }}
$$

c. Penentuan rentang skala

Rentang skala digunakan sebagai dasar pembuatan nilai interval masing-masing dari lima skala penilaian, seperti dimuat pada Tabel 1

Tabel 1. Interval nilai skala rataan skor

\begin{tabular}{cc}
\hline Interval Skor & Kategori \\
\hline $1,00-1,80$ & Sangat rendah \\
$1,81-2,60$ & Rendah \\
$2,61-3,40$ & Cukup \\
$3,41-4,20$ & Tinggi \\
$4,21-5,00$ & Sangat Tinggi \\
\hline
\end{tabular}

2. Analisis korelasi rank pearson

Analisis korelasi rank pearson dilakukan untuk mengetahui ada atau tidaknya hubungan antara persepsi pelatihan yang telah diikuti dengan peningkatan kinerja setelah pelatihan, dan mengukur tingkat keeratan hubungannya. Uji korelasi dilakukan pada perubah penilaian kebutuhan pelatihan, peubah pelaksanaan pelatihan, perubah evaluasi pelatihan dengan peningkatan kinerja. Pengolahan data menggunakan software Statistic Package for Social Science (SPSS). Hasil olah data SPSS akan memperlihatkan nilai koefisien korelasi dan nilai nyatanya. Penafsiran angka korelasi yang menggambarkan besar dan kecilnya hubungan terdapat pada Tabel 2.

Tabel 2. Kategori hubungan korelasi

\begin{tabular}{ll}
\hline Besaran Angka Korelasi & Kategori Hubungan \\
\hline Correlation coefficient $=0,0$ & Tidak ada hubungan \\
Correlation coefficient $<0,5$ & Rendah/lemah \\
Correlation coefficient $>0,5$ & Kuat \\
Correlation coefficient $=1,0$ & Hubungan sempurna \\
\hline
\end{tabular}

Sumber: Santoso (2012).

\section{Training need assessment tools (TNA-T)}

Dahiya dan Jha (2011) melakukan penelitian terhadap beberapa metode analisis kebutuhan pelatihan dari 1979 hingga 2009 diketahui bahwa metode yang paling sering digunakan adalah dengan mengetahui kesenjangan kompetensi karyawan dengan kompetensi yang diharapkan perusahaan. 
Salah satu alat pengukuran dalam analisis kebutuhan pelatihan dengan menganalisis kesenjangan kompetensi karyawan dengan kompetensi yang diharapkan perusahaan adalah TNA-T yang dikembangkan oleh Mc Cann dan Tashima tahun 1994. Analisis ini bertujuan untuk mendapatkan kebutuhan pelatihan yang sesuai dengan kondisi sebenarnya dalam menunjang pekerjaan. Langkah-langkah yang dilakukan menganalisis kebutuhan pelatihan menggunakan TNA-T seperti pada Gambar 1.

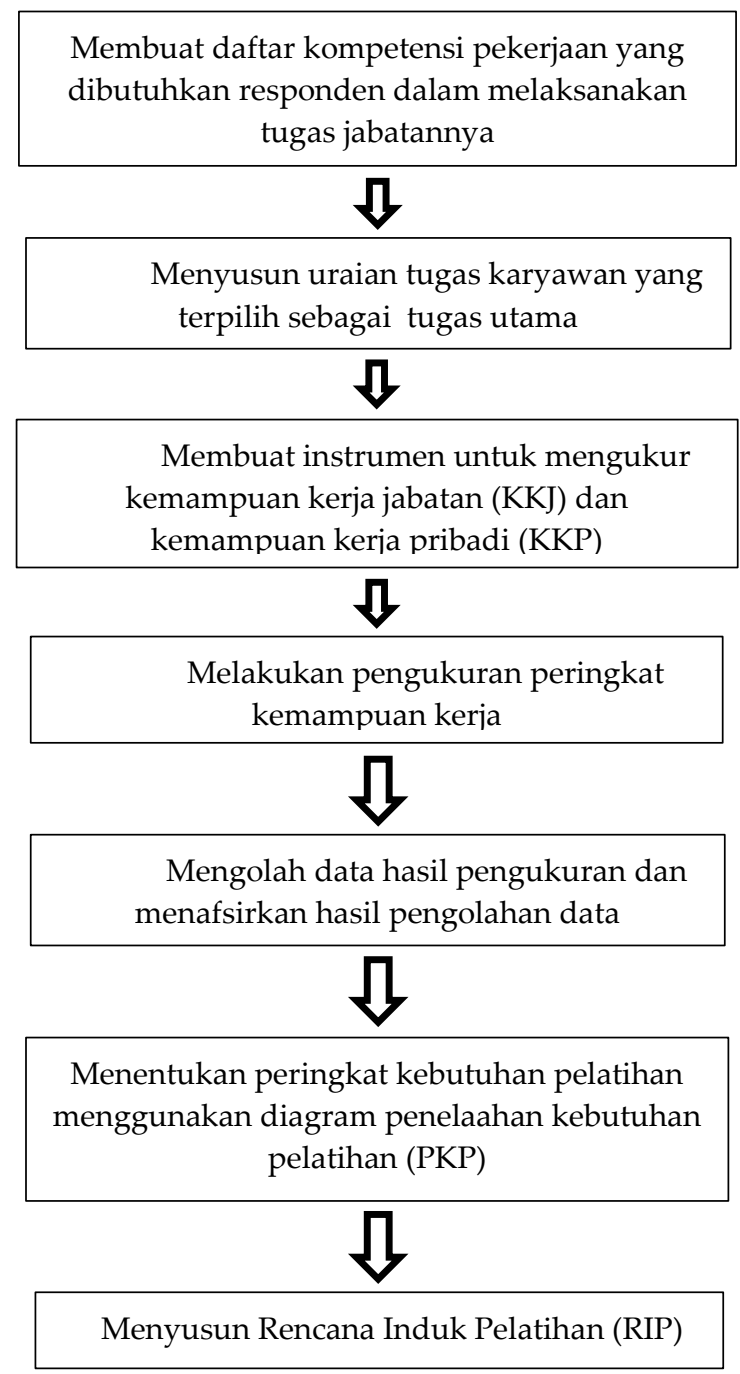

Sumber: Tashima dan McCann (1994).

Gambar 1. Langkah-langkah analisis kebutuhan pelatihan

Pengukuran peringkat kompetensi kerja yang tercermin pada KKJ dan KKP dilakukan secara kuantitatif dengan nilai skala 0-9 dengan ketentuan skala 0-3 mengindikasikan peringkat KKJ dan KKP rendah, skala 3-6 mengindikasikan peringkat KKJ dan KKP sedang dan skala 6-9 mengindikasikan peringkat KKJ dan KKP tinggi.
Selanjutnya, menentukan kebutuhan pelatihan dan tingkat kebutuhannya.

a. Menentukan kebutuhan pelatihan dengan menghitung selisih antara KKJ dengan KKP. Jika KKJ-KKP > 1, maka pelatihan dibutuhkan.

b. Pengolahan dan interpretasi hasil perhitungan dari kuisioner KKP dan KKJ. Nilai KKP dan KKJ yang dinilai oleh responden kemudian dibuat menjadi nilai KKP rataan dari keseluruhan responden setiap divisinya dan KKJ. Dalam penelitian ini, nilai KKJ merupakan nilai tunggal karena merupakan nilai standar kompetensi kerja yang dimiliki perusahaan, sedangkan nilai KKP diperoleh dari penilaian responden terhadap kemampuan pribadinya dan nilai KKP dari atasannya. Rumus yang digunakan untuk menghitung KKP rataan dari keseluruhan responden setiap divisi adalah:

$$
\mathrm{KKP} \text { rataan }=\frac{\sum[\mathrm{i}, \mathrm{ni}]}{\mathrm{N}}
$$

Dimana: $\mathrm{i}=$ Nilai Skala, $\mathrm{ni}=\mathrm{Jumlah}$ responden yang memilih skala i dalam indikator, $\mathrm{N}=$ Jumlah responden keseluruhan

c. Menentukan peringkat kebutuhan pelatihan dengan diagram PKP melalui penentuan titik potong $\mathrm{KKJ}$ rataan dengan KKP rataan. Titik perpotongan dua nilai akan terletak pada salah satu keempat bidang, yaitu bidang A, B, C, atau D.

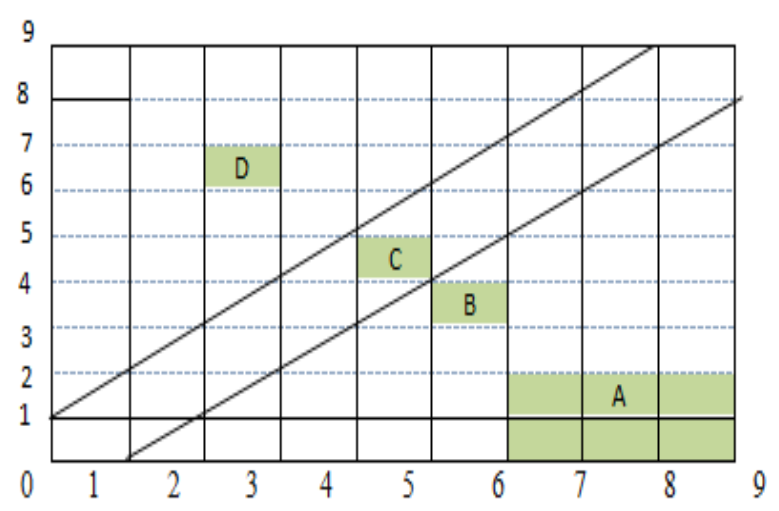

Sumber: Tashima dan McCann (1994)

Gambar 2. Diagram penelaahan kebutuhan pelatihan

Penafsiran peringkat kebutuhan pelatihan menggunakan sebuah diagram memuat ikhtisar penafsiran diagram PKP pada Tabel 3. 
Tabel 3. Matriks ikhtisar penafsiran diagram penelaahan kebutuhan pelatihan

\begin{tabular}{|c|c|c|}
\hline $\begin{array}{l}\text { Letak titik } \\
\text { potong KKJ- } \\
\text { KKP dalam } \\
\text { Diagram PKP }\end{array}$ & $\begin{array}{l}\text { Imbangan } \\
\text { KKP dengan } \\
\text { KKJ }\end{array}$ & $\begin{array}{l}\text { Peringkat kebutuhan } \\
\text { pelatihan untuk } \\
\text { peningkatan } \\
\text { kemampuan kerja }\end{array}$ \\
\hline Bidang A & $\begin{array}{l}\text { KKP jauh di } \\
\text { bawah KKJ }\end{array}$ & $\begin{array}{l}\text { Sangat perlu } \\
\text { pelatihan/mendesak }\end{array}$ \\
\hline Bidang B & $\begin{array}{l}\text { KKJ dan } \\
\text { KKP tidak } \\
\text { jauh berbeda }\end{array}$ & $\begin{array}{l}\text { Perlu pelatihan tetapi } \\
\text { tidak mendesak } \\
\text { sekali }\end{array}$ \\
\hline Bidang C & $\begin{array}{l}\text { KKP dengan } \\
\mathrm{KKJ} \\
\text { seimbang }\end{array}$ & $\begin{array}{l}\text { Tidak perlu pelatihan/ } \\
\text { mencukupi } \\
\text { persyaratan }\end{array}$ \\
\hline Bidang D & $\begin{array}{l}\text { KKP } \\
\text { menyamai/ } \\
\text { melebihi } \\
\text { KKJ }\end{array}$ & $\begin{array}{l}\text { Tidak memerlukan } \\
\text { pelatihan (kemung- } \\
\text { kinan pengembangan } \\
\text { karir) }\end{array}$ \\
\hline
\end{tabular}

Sumber: Tashima dan McCann (1994).

\section{HASIL DAN PEMBAHASAN}

\section{Persepsi responden terhadap program pelatihan}

Analisis persepsi terhadap program pelatihan yang telah diikuti digunakan untuk mengetahui persepsi responden terhadap pelatihan yang dilaksanakan perusahaan. Analisis persepsi terhadap program pelatihan meliputi persepsi mengenai penilaian kebutuhan pelatihan, pelaksanaan pelatihan dan evaluasi pelatihan. Hal tersebut dimuat pada Tabel 4.

Secara keseluruhan, persepsi responden terhadap pelatihan yang diadakan oleh perusahaan yaitu menyatakan puas. Pada peubah analisis kebutuhan pelatihan, karyawan di subdivisi produksi dan subdivisi maintenance menilai puas terhadap sistem pemilihan peserta pelatihan, karena pemilihan peserta dilaksanakan secara terbuka dengan melihat kondisi karyawan yang membutuhkan pelatihan, sehingga tujuan pelatihan direalisasikan. Peserta pelatihan menilai cukup untuk keterlibatan dalam identifikasi bidang-bidang yang perlu ditingkatkan di perusahaan sebagai materi pelatihan.

Pada subdivisi quality control (QC), karyawan merasa puas dengan diikutsertakan dalam proses penilaian kebutuhan pelatihan dengan cara mengevaluasi pribadi kinerja masing-masing individu pada subdivisi ini. Karyawan subdivisi QC menilai cukup untuk keterlibatannya dalam identifikasi bidang-bidang yang perlu ditingkatkan di perusahaan sebagai materi pelatihan. Oleh karena itu, penilaian kebutuhan pelatihan selain dengan metode evaluasi kinerja pribadi juga dilakukan dengan memberikan pendapatnya mengenai identifikasi bidang-bidang yang perlu ditingkatkan perusahaan (kinerja perusahaan).

Pada subdivisi PPIC, karyawan merasa puas dengan sistem pemilihan peserta yang bersifat terbuka dan keterlibatan karyawan dalam identifikasi bidang-bidang yang perlu ditingkatkan perusahaan, namun setelah pelatihan dilakukan, peserta pelatihan merasa belum puas dengan kesesuaian jenis pelatihan dengan kebutuhan peserta pelatihan, karena pelatihan yang dilakukan tidak mencakup bidang-bidang yang perlu ditingkatkan. Dari keempat subdivisi tersebut, diperoleh skor rataan persepsi terhadap analisis kebutuhan pelatihan yaitu pada subdivisi produksi, QC dan PPIC dengan persepsi rataan puas sedangkan pada subdivisi Maintenance dengan persepsi rataan cukup puas.

Pada peubah pelaksanaan pelatihan, karyawan pada subdivisi produksi menilai puas terhadap materi pelatihan yang diberikan, karena sudah sesuai dengan tujuan pelatihan. Selain itu, karyawan puas terhadap instruktur pelatihan karena sangat menguasai materi yang diberikan, namun peserta pelatihan hanya memberikan penilaian cukup untuk waktu dan durasi pelatihan. Waktu dan durasi pelatihan yang sudah dilakukan pada subdivisi produksi rataan hanya berkisar 45-60 menit per sesi. Hal ini dikarenakan banyaknya materi pelatihan dengan durasi lama pelatihan yang dilakukan satu hari.

Pada subdivisi maintenance, peserta pelatihan merasa puas dengan kenyamanan tempat pelatihan, karena berada di lokasi perusahaan yang sebagian besar dekat dengan tempat tinggal karyawan namun peserta pelatihan menilai tidak puas dengan kelengkapan sarana dan prasarana pelatihan. Hal ini dikarenakan keterbatasan perusahaan dalam pengadaan alat atau mesin yang mendukung kegiatan pelatihan sehingga pelatihan selanjutnya dilakukan dengan cara tour places yang menyediakan alat atau mesin yang mendukung pelatihan.

Pada subdivisi QC, peserta pelatihan menilai puas dengan instruktur pelatihan, karena menguasai materi yang diberikan, namun sama seperti subdivisi maintenance bahwa kelengkapan sarana dan prasarana pelatihan masih dinilai cukup. Pada subdivisi PPIC, peserta pelatihan merasa puas dengan kelengkapan sarana dan prasarana, namun menilai cukup puas dengan ketepatan jadwal pelatihan karena sebagian besar 
karyawan mengaku pelaksanaan pelatihan dilakukan di sela-sela hari kerja efektif. Dari keempat subdivisi tersebut, diperoleh nilai rataan persepsi terhadap peubah kegiatan evaluasi pelatihan. Pada subdivisi produksi dengan penilaian persepsi rataan puas sedangkan pada subdivisi PPIC, maintenance dan QC memiliki penilaian persepsi rataan cukup puas.

Pada peubah evaluasi pelatihan, karyawan pada subdivisi produksi menilai puas terhadap adanya pengadaan kegiatan monitoring berkala sebagai tindak lanjut evaluasi pelatihan yang dilakukan setiap tiga bulan sekali, namun peserta pelatihan menilai cukup keterlibatan peserta terhadap kegiatan evaluasi pelatihan. Peserta pelatihan menilai kegiatan evaluasi hanya bersifat formalitas, karena tidak dilibatkan dalam hal mengkaji kebijakan yang dilakukan menurut hasil evaluasi tersebut.

Pada subdivisi maintenance, peserta pelatihan menilai cukup puas dengan metode evaluasi pelatihan yang mudah dimengerti sehingga tidak memerlukan penjelasan ulang. Keterlibatan peserta terhadap kegiatan evaluasi pelatihan, pengadaan kegiatan monitoring berkala sebagai tindak lanjut evaluasi pelatihan dan efektivitas waktu dalam melakukan kegiatan evaluasi pelatihan juga dinilai cukup puas.

Tabel 4. Persepsi responden terhadap pelatihan

\begin{tabular}{|c|c|c|c|c|c|}
\hline \multirow[b]{2}{*}{ Item } & \multirow[b]{2}{*}{ Peubah } & \multicolumn{4}{|c|}{ Skor } \\
\hline & & $\begin{array}{l}\text { Subdivisi } \\
\text { Produksi }\end{array}$ & $\begin{array}{c}\text { Subdivisi } \\
\text { Maintenance }\end{array}$ & $\begin{array}{c}\text { Subdivisi } \\
\text { QC }\end{array}$ & $\begin{array}{l}\text { Subdivisi } \\
\text { PPIC }\end{array}$ \\
\hline \multicolumn{6}{|c|}{ Analisis kebutuhan pelatihan } \\
\hline $\mathrm{X}_{1}$ & $\begin{array}{l}\text { Diikutsertakan dalam proses penilaian } \\
\text { kebutuhan pelatihan }\end{array}$ & 4,07 & 3,38 & 3,70 & 3,50 \\
\hline $\mathrm{X}_{2}$ & $\begin{array}{l}\text { Kesesuaian pelatihan dengan } \\
\text { kebutuhan tugas pekerjaan }\end{array}$ & 3.93 & 3,38 & 3,38 & 3,31 \\
\hline $\mathrm{X}_{3}$ & $\begin{array}{l}\text { Sistem pemilihan peserta pelatihan } \\
\text { terbuka dan tepat }\end{array}$ & 4.25 & 3,46 & 3,59 & 3,63 \\
\hline $\mathrm{X}_{4}$ & $\begin{array}{l}\text { Keterlibatan identifikasi bidang-bidang } \\
\text { yang perlu ditingkatkan di perusahaan } \\
\text { sebagai materi pelatihan }\end{array}$ & 3.44 & 3,30 & 3,29 & 3,63 \\
\hline & Rataan & 3,92 & 3,38 & 3,59 & 3,52 \\
\hline \multicolumn{6}{|c|}{ Pelaksanaan pelatihan } \\
\hline $\mathrm{X}_{5}$ & $\begin{array}{l}\text { Materi pelatihan yang diberikan sesuai } \\
\text { dengan tujuan pelatihan }\end{array}$ & 4,19 & 2,85 & 3,29 & 3,63 \\
\hline$X_{6}$ & $\begin{array}{l}\text { Instruktur pelatihan menguasai materi } \\
\text { yang diberikan }\end{array}$ & 4,19 & 3,23 & 4,12 & 3,37 \\
\hline $\mathrm{X}_{7}$ & $\begin{array}{l}\text { Kelengkapan sarana dan prasarana } \\
\text { pelatihan }\end{array}$ & 3,88 & 2,31 & 2,88 & 3,94 \\
\hline $\mathrm{X}_{8}$ & Waktu dan durasi pelatihan & 3,31 & 2,85 & 3,12 & 3,62 \\
\hline$X_{9}$ & $\begin{array}{l}\text { Ketepatan jadwal pelaksanaan } \\
\text { pelatihan }\end{array}$ & 3,56 & 3,23 & 3,06 & 3,25 \\
\hline $\mathrm{X}_{10}$ & Kenyamanan tempat pelatihan & 3,56 & 3,69 & 3,18 & 3,69 \\
\hline $\mathrm{X}_{11}$ & $\begin{array}{l}\text { Metode pelatihan yang diikuti sesuai } \\
\text { dengan karakteristik peserta }\end{array}$ & 3,88 & 3,38 & 3,62 & 3,75 \\
\hline & Rataan & 3,79 & 3,07 & 3,32 & 3,61 \\
\hline \multicolumn{6}{|c|}{ Evaluasi pelatihan } \\
\hline $\mathrm{X}_{12}$ & Kemudahan metode evaluasi pelatihan & 3,75 & 3,30 & 3,88 & 3,12 \\
\hline$X_{13}$ & $\begin{array}{l}\text { keterlibatan peserta terhadap kegiatan } \\
\text { evaluasi pelatihan }\end{array}$ & 3,38 & 3,07 & 2,88 & 3,12 \\
\hline$X_{14}$ & $\begin{array}{l}\text { Pengadaan kegiatan monitoring } \\
\text { berkala sebagai tindak lanjut evaluasi } \\
\text { pelatihan }\end{array}$ & 3,88 & 3,07 & 3,18 & 3,31 \\
\hline $\mathrm{X}_{15}$ & $\begin{array}{l}\text { Efektivitas waktu dalam melakukan } \\
\text { kegiatan evaluasi pelatihan }\end{array}$ & 3,69 & 3,07 & 3,00 & 3,56 \\
\hline & Rataan & 3,67 & 3,13 & 3,24 & 3,28 \\
\hline
\end{tabular}

Keterangan rentang kriteria: Rentang 1-1,8: Sangat Tidak Puas, 1,9-2,6: Tidak puas, 2,7-3,4: Cukup puas, 3,5-4,2: Puas, 4,3-5: Sangat Puas. 
Pada subdivisi QC, peserta pelatihan memberikan penilaian puas terhadap metode evaluasi pelatihan yang sangat mudah dengan waktu singkat yaitu memfasilitasi beberapa peserta pelatihan untuk mengajukan pendapatnya terkait dengan pelaksanaan pelatihan. Metode evaluasi ini ternyata dinilai cukup oleh peserta pelatihan, karena kurangnya keterlibatan peserta terhadap kegiatan evaluasi pelatihan, dimana hanya beberapa peserta yang dapat mengajukan pendapatnya terkait pelaksanaan pelatihan.

Pada subdivisi PPIC, peserta pelatihan menilai puas dengan efektifitas waktu dalam melakukan kegiatan evaluasi pelatihan, namun kemudahan metode evaluasi pelatihan dan keterlibatan peserta terhadap kegiatan evaluasi pelatihan masih dinilai cukup. Keterbatasan waktu pelatihan menyebabkan waktu evaluasi pelatihan yang singkat, sehingga metode evaluasi yang hanya dinilai secara garis besar oleh tim manajemen pelatihan dan satu perwakilan dari peserta pelatihan.

Dari keempat subdivisi tersebut, diperoleh rataan persepsi terhadap kegiatan evaluasi pelatihan. Pada subdivisi produksi dengan persepsi rataan puas, sedangkan pada sub divisi PPIC, maintenance dan QC dengan persepsi rataan cukup puas. Persepsi responden terhadap pelatihan secara keseluruhan untuk subdivisi PPIC dan produksi puas, sedangkan pada maintenance dan QC menilai cukup puas. Rincian hal tersebut dapat dilihat pada Tabel 4 .

\section{Persepsi responden terhadap peningkatan kinerja}

Pada peubah peningkatan kinerja individu, karyawan subdivisi produksi memberikan penilaian sangat tinggi terhadap peningkatan keterampilan dan kedisiplinan. Pada subdivisi maintenance, peserta pelatihan memberikan persepsi tinggi terhadap peningkatan mematuhi SOP perusahaan, namun kecocokan bidang pekerjaan dengan minat bakat dan peningkatan keterampilan masih dinilai sedang. Pada subdivisi QC, persepsi tinggi terhadap peningkatan pengetahuan, namun persepsi terhadap peningkatan kesesuaian perilaku dengan Standar Operating Procedures (SOP) perusahaan dan peningkatan motivasi masih dinilai sedang. Pada subdivisi PPIC, peserta pelatihan memberikan persepsi tinggi mengenai peningkatan kecocokan bidang pekerjaan dengan minat dan bakat karyawan, namun peningkatan motivasi dalam bekerja masih dinilai sedang.
Pada peubah peningkatan kinerja kelompok, peserta pelatihan di subdivisi produksi memberikan penilaian sangat tinggi terhadap peningkatan kerjasama dengan rekan kerja dan peningkatan rasa bertanggungjawab atas pelaksanaan tugas kelompok. Pada subdivisi maintenance memberikan persepsi penilaian tinggi dalam bertanggungjawab atas pelaksanaan tugas kelompok, namun untuk persepsi mengenai peningkatan kemampuan memotivasi rekan kerja dan membimbing rekan kerja dalam melakukan pekerjaan dinilai sedang. Pada subdivisi QC, peningkatan kerjasama dengan bawahan maupun rekan kerja lainnya dinilai tinggi, namun peningkatan kemampuan dalam mengembangkan komunikasi dengan atasan, rekan kerja, bawahan untuk kelancaran tugas dinilai rendah. Pada subdivisi PPIC, persepsi peserta pelatihan tinggi terhadap peningkatan membimbing rekan kerja dalam melakukan pekerjaan dan meyakinkan rekan kerja agar mengikuti rencana kerja.

Pada peubah peningkatan kinerja perusahaan, peserta pelatihan di subdivisi produksi memberikan persepsi nilai tinggi untuk peningkatan kinerja perusahaan dalam menyesuaikan budaya perusahaan dengan karakteristik karyawan dan peningkatan pengembangan karir karyawan di perusahaan. Pada subdivisi maintenance, persepsi tinggi untuk pengurangan jumlah turnover karyawan di perusahaan dan peningkatan perusahaan dalam menyesuaikan budaya perusahaan dengan karakteristik karyawan dinilai sedang. Pada subdivisi QC, pengurangan jumlah turnover karyawan dinilai tinggi dan pengaruh pelatihan terhadap pengembangan karir peserta pelatihan di perusahaan masih dinilai sedang. Pada subdivisi PPIC, skor tertinggi pada peningkatan perusahaan dalam menyesuaikan budaya perusahaan dengan karakteristik karyawan dan skor terendah yaitu peningkatan kemampuan perusahaan dalam menyelesaikan permasalahan di kondisi kritis, namun keduanya berada dalam rentang kategori tinggi.

Dari rataan persepsi peningkatan kinerja sesudah pelatihan, persepsi kinerja karyawan subdivisi produksi, PPIC, QC meningkat, sedangkan persepsi kinerja karyawan subdivisi maintenance setelah pelatihan adalah sedang. Dalam hal ini perusahaan harus mempertahankan kinerja tinggi subdivisi produksi dan PPIC dengan mengadakan pelatihan konsisten dan meningkatkan kinerja, sedangkan subdivisi maintenance dan QC mengadakan pelatihan sesuai kebutuhan (Tabel 5). 
Tabel 5. Persepsi responden terhadap peningkatan kinerja setelah pelatihan

\begin{tabular}{|c|c|c|c|c|c|}
\hline Item & Peubah & $\begin{array}{c}\text { Divisi } \\
\text { Produksi }\end{array}$ & $\begin{array}{c}\text { Divisi } \\
\text { Maintenance }\end{array}$ & $\begin{array}{c}\text { Divisi } \\
Q C\end{array}$ & $\begin{array}{l}\text { Divisi } \\
\text { PPIC }\end{array}$ \\
\hline \multicolumn{6}{|c|}{ Peningkatan kinerja individu } \\
\hline $\mathrm{X}_{16}$ & $\begin{array}{l}\text { Peningkatan pengetahuan sesuai dengan standar } \\
\text { kemampuan kerja pekerjaan }\end{array}$ & 4,25 & 3,62 & 3,82 & 3,56 \\
\hline $\mathrm{X}_{17}$ & $\begin{array}{l}\text { Peningkatan keterampilan sesuai dengan standar } \\
\text { kemampuan kerja pekerjaan }\end{array}$ & 4,56 & 3,15 & 3,76 & 4,12 \\
\hline $\mathrm{X}_{18}$ & $\begin{array}{l}\text { Peningkatan kesesuaian perilaku dengan SOP } \\
\text { perusahaan }\end{array}$ & 4,38 & 3,69 & 3,24 & 3,75 \\
\hline $\mathrm{X}_{19}$ & Peningkatan motivasi dalam bekerja & 4,19 & 3,54 & 3,24 & 3,25 \\
\hline$X_{20}$ & $\begin{array}{l}\text { Kecocokan deskripsi peran pekerjaan dengan minat } \\
\text { dan bakat karyawan }\end{array}$ & 4,13 & 3,15 & 3,59 & 4,19 \\
\hline \multirow[t]{2}{*}{$\mathrm{X}_{21}$} & Peningkatan kedisiplinan dalam bekerja & 4,56 & 3,31 & 3,65 & 3,63 \\
\hline & Rataan kinerja individu & 4,35 & 3,41 & 3,55 & 3,75 \\
\hline \multicolumn{6}{|c|}{ Peningkatan kinerja kelompok } \\
\hline $\mathrm{X}_{22}$ & $\begin{array}{l}\text { Peningkatan kemampuan dalam meyakinkan rekan } \\
\text { kerja agar mengikuti rencana kerja }\end{array}$ & 4,00 & 3,15 & 3,65 & 3,50 \\
\hline$X_{23}$ & $\begin{array}{l}\text { Peningkatan kemampuan dalam memotivasi rekan } \\
\text { kerja dalam melakukan pekerjaan }\end{array}$ & 4,25 & 2,69 & 4,00 & 3,56 \\
\hline $\mathrm{X}_{24}$ & $\begin{array}{l}\text { Peningkatan kemampuan dalam membimbing } \\
\text { rekan kerja dalam melakukan pekerjaan }\end{array}$ & 3,69 & 2,69 & 3,41 & 4,62 \\
\hline$X_{25}$ & $\begin{array}{l}\text { Peningkatan kemampuan dalam melakukan } \\
\text { pengawasan rekan kerja terhadap pelaksanaan kerja }\end{array}$ & 4,00 & 3,00 & 3,29 & 3,52 \\
\hline $\mathrm{X}_{26}$ & $\begin{array}{l}\text { Peningkatan kemampuan dalam bertanggungjawab } \\
\text { atas pelaksanaan tugas rekan kerja }\end{array}$ & 3,5 & 3,31 & 3,24 & 4,56 \\
\hline $\mathrm{X}_{27}$ & $\begin{array}{l}\text { Peningkatan kemampuan dalam mengembangkan } \\
\text { komunikasi dengan atasan, rekan kerja, bawahan } \\
\text { untuk kelancaran tugas }\end{array}$ & 4,31 & 3,08 & 2,59 & 4,12 \\
\hline $\mathrm{X}_{28}$ & $\begin{array}{l}\text { Peningkatan kemampuan dalam bekerjasama } \\
\text { dengan bawahan maupun rekan kerja lainnya }\end{array}$ & 4,38 & 3,00 & 3,88 & 4,56 \\
\hline & Rataan kinerja kelompok & 4,02 & 2,99 & 3,44 & 4,07 \\
\hline \multicolumn{6}{|c|}{ Peningkatan kinerja perusahaan } \\
\hline $\mathrm{X}_{29}$ & $\begin{array}{l}\text { Peningkatan kemampuan perusahaan } \\
\text { menyelesaikan permasalahan dalam situasi dan } \\
\text { kondisi kritis }\end{array}$ & 4,31 & 3,39 & 3,88 & 3,25 \\
\hline $\mathrm{X}_{30}$ & $\begin{array}{l}\text { Pengurangan jumlah turnover karyawan di } \\
\text { perusahaan }\end{array}$ & 4,25 & 3,00 & 3,47 & 4,12 \\
\hline $\mathrm{X}_{31}$ & $\begin{array}{l}\text { Peningkatan pemahaman kesesuaian budaya } \\
\text { perusahaan dengan karakteristik, karyawan }\end{array}$ & 4,38 & 2,92 & 3,47 & 4,56 \\
\hline $\mathrm{X}_{32}$ & $\begin{array}{l}\text { Peningkatan pengembangan karir karyawan di } \\
\text { perusahaan }\end{array}$ & 3,88 & 3,31 & 3,35 & 4,12 \\
\hline & Rataan kinerja perusahaan & 4,21 & 3,15 & 3,54 & 4,01 \\
\hline & Rataan kinerja & 4,19 & 3,18 & 3,51 & 3,94 \\
\hline
\end{tabular}

Keterangan rentang kriteria: Rentang 1-1,8: Sangat tidak meningkat, 1,9-2,6: Tidak meningkat, 2,7-3,4: Sedang, 3,54,2: Meningkat, 4,3-5: Sangat meningkat.

\section{Hubungan pelatihan dengan kinerja}

Pengetahuan mengenai persepsi peningkatan kinerja karyawan perlu dilakukan karena kinerja karyawan akan mempengaruhi efektivitas organisasi/perusahaan (Hameed et al. 2011).

Hubungan pelatihan dengan kinerja diketahui melalui analisis korelasi. Analisis korelasi dilakukan untuk mengetahui keeratan hubungan persepsi pelatihan yang sudah diikuti dengan persepsi peningkatan kinerja setelah dilakukan pelatihan. Teknik analisis yang digunakan korelasi rank pearson dengan bantuan SPSS 16.0. Hasil analisis korelasi terdapat pada Tabel 6.

Dari Tabel 6 dijelaskan bahwa peubah sub pelatihan memiliki hubungan searah dengan kinerja. Hal ini diketahui dari hubungan antar keduanya bernilai positif artinya semakin baik kegiatan analisis kebutuhan pelatihan, pelaksanaan pelatihan dan evaluasi pelatihan maka semakin meningkatkan kinerja karyawan. Pada penelitian yang dilakukan oleh Khan (2011) dan Elnaga (2013) menegaskan bahwa pelatihan memiliki 
hubungan positif pada peningkatan kinerja karyawan. Studi oleh Fokno (2014) menunjukkan hubungan positif dan kuat pelatihan dengan kinerja.

Tabel 6. Hubungan pelatihan dengan kinerja

\begin{tabular}{|c|c|c|}
\hline \multirow[b]{2}{*}{ Peubah } & \multicolumn{2}{|c|}{ Hasil } \\
\hline & $\begin{array}{l}\text { Koefisien } \\
\text { korelasi }\end{array}$ & $\begin{array}{l}\text { Nilai } \\
\text { signifikansi }\end{array}$ \\
\hline & \multicolumn{2}{|c|}{ Subdivisi produksi } \\
\hline Pelatihan & $0,775^{* *}$ & 0 \\
\hline \multicolumn{3}{|l|}{ Peubah Subpelatihan } \\
\hline $\begin{array}{l}\text { AKP (Analisis } \\
\text { Kebutuhan Pelatihan) }\end{array}$ & $0,545^{*}$ & 0,029 \\
\hline $\begin{array}{l}\text { PP (Pelaksanaan } \\
\text { Pelatihan) }\end{array}$ & $0,671^{* *}$ & 0,004 \\
\hline EP (Evaluasi Pelatihan) & $0,809^{* *}$ & 0 \\
\hline \multicolumn{3}{|c|}{ Subdivisi maintenance } \\
\hline Pelatihan & 0,369 & 0,210 \\
\hline \multicolumn{3}{|l|}{ Peubah Subpelatihan } \\
\hline $\begin{array}{l}\text { AKP (Analisis } \\
\text { Kebutuhan Pelatihan) }\end{array}$ & 0,244 & 0,422 \\
\hline $\begin{array}{l}\text { PP (Pelaksanaan } \\
\text { Pelatihan) }\end{array}$ & 0,218 & 0,475 \\
\hline EP (Evaluasi Pelatihan) & 0,476 & 0,100 \\
\hline \multicolumn{3}{|c|}{ Subdivisi PPIC } \\
\hline Pelatihan & $0,616^{*}$ & 0,011 \\
\hline \multicolumn{3}{|l|}{ Peubah Subpelatihan } \\
\hline $\begin{array}{l}\text { AKP (Analisis } \\
\text { Kebutuhan Pelatihan) }\end{array}$ & $0,745^{* *}$ & 0,001 \\
\hline $\begin{array}{l}\text { PP (Pelaksanaan } \\
\text { Pelatihan) }\end{array}$ & $0,805^{* *}$ & 0 \\
\hline EP (Evaluasi Pelatihan) & $0,515^{*}$ & 0,041 \\
\hline \multicolumn{3}{|c|}{ Sub divisi Quality Control } \\
\hline Pelatihan & $0,705^{* *}$ & 0,002 \\
\hline Peubah Sub Pelatihan & & \\
\hline $\begin{array}{l}\text { AKP (Analisis } \\
\text { Kebutuhan Pelatihan) }\end{array}$ & $0,704^{* *}$ & 0,002 \\
\hline $\begin{array}{l}\text { PP (Pelaksanaan } \\
\text { Pelatihan) }\end{array}$ & $0,788^{* *}$ & 0 \\
\hline EP (Evaluasi Pelatihan) & $0,691^{* *}$ & 0,002 \\
\hline
\end{tabular}

Pada subdivisi produksi, subdivisi PPIC dan subdivisi QC memiliki kategori hubungan kuat untuk keseluruhan peubah pelatihan, AKP, PP dan EP. Analisis hubungan sesuai persepsi responden pada subdivisi tersebut dengan rataan responden memberikan penilaian tinggi untuk pelatihan dan peningkatan kinerja. Pada sub divisi maintenance memiliki hubungan rendah untuk pelatihan dengan kinerja. Hubungan rendah diasumsikan karena penilaian responden cenderung beragam terhadap pelatih-an seperti pada pelaksanaan pelatihan responden divisi maintenance menilai tidak puas dengan kelengkapan sarana dan prasarana, namun ada beberapa responden yang menilai puas.

Uji nyata koefisien korelasi digunakan untuk menguji hubungan yang terjadi itu berlaku untuk populasi (digeneralisasi). Dari Tabel 6 diketahui bahwa pada subdivisi produksi, PPIC, QC memiliki hubungan yang nyata karena nilai nyata kurang dari 0,05 sehingga ho (tidak ada hubungan nyata persepsi pelatihan dengan persepsi kinerja) ditolak. Pada subdivisi maintenance nilai signifikansi lebih besar dari 0,05 , sehingga $\mathrm{h}_{0}$ (tidak ada hubungan secara signifikan antara persepsi pelatihan dengan persepsi kinerja) diterima.

\section{Kebutuhan pelatihan manajer divisi workshop}

Hasil analisis nilai KKJ dan KKP untuk manajer divisi workshop terdapat sepuluh deskripsi tugas yang membutuhkan pelatihan dengan gap KKJ-KKP $>1$. Deskripsi tugas tersebut diolah melalui diagram PKP. Hasil olah diagram PKP untuk semua deskripsi tugas yang membutuhkan pelatihan menunjukkan bahwa letak titik potong semua deskripsi tugas berada pada bidang B yang artinya deskripsi tugas tersebut membutuhkan pelatihan tetapi tidak mendesak.

Dari 10 deskripsi tugas yang membutuhkan pelatihan, perlu diurutkan jenisnya untuk merencanakan prioritas jenis pelatihan menurut kebutuhan. Prioritas pelatihan diurutkan berdasarkan besarnya gap KKJ dan KKP yang dihasilkan. Semakin besar gap, maka semakin diutamakan proritasnya. Prioritas pelatihan pertama bagi manajer divisi workshop meliputi kemampuan menyusun rencana kerja dan anggaran tahunan untuk divisi, karena penyusunan rencana kerja dan anggaran tahunan yang baik dan tersistem menyebabkan divisi akan berjalan sesuai target yang direncanakan, penjadwalan jangka pendek dan menengah pada saat produksi serta kemampuan mengembangkan staf sesuai dengan bidang pekerjaannya.

Deskripsi tugas prioritas kedua pada bidang kompetensi intelektual yaitu menganalisis masalah, serta memberikan alternatif pemecahannya dan mengambil keputusan dalam kondisi kritis dengan tepat. Pada bidang kompetensi emosional yaitu mengendalikan diri ketika menghadapi masalah. Pada bidang kompetensi terkait dengan bidang pekerjaan, yaitu melakukan evaluasi dan pelaporan tiap program kerja yang telah dilaksanakan, penggunaan teknologi untuk 
kegiatan produksi, memastikan keselamatan kerja karyawan dan tanggungjawab terhadap kesesuaian pekerjaan dengan kinerja staff di subdivisi Workshop.

\section{Kebutuhan pelatihan sub divisi produksi}

Hasil analisis nilai KKJ dan KKP untuk supervisor divisi workshop terdapat tiga deskripsi tugas yang membutuhkan pelatihan dengan gap KKJ-KKP >1. Hasil olah diagram PKP untuk semua deskripsi tugas membutuhkan pelatihan yang digambarkan letak titik potong semua deskripsi tugas yang berada pada bidang B dengan kondisi karyawan membutuhkan pelatihan tetapi tidak mendesak. Urutan bidang kompetensi pekerjaan yang membutuhkan pelatihan adalah keselamatan kerja, menyusun rencana produksi mingguan dengan mananjer divisi workshop dan membuat rencana jangka pendek untuk deskripsi tugas yang diberikan manajer.

Hasil analisis nilai KKJ dan KKP untuk staff subdivisi produksi terdapat enam deskripsi tugas membutuhkan pelatihan. Hasil olah diagram PKP menunjukkan kemampuan menggunakan alat keselamatan kerja berada di bidang A artinya sangat mendesak dilalukan pelatihan sehingga deskripsi tugas ini menjadi prioritas pertama. Nilai KKP untuk penggunaan alat keselamatan kerja sangat rendah dikarenakan supervisor di subdivisi produksi menilai stafnya masih banyak yang tidak menggunakan masker dan sarung tangan. Staf divisi produksi juga menilai pemakaian alat keselamatan kerja masih belum menjadi kebutuhan wajib, karena staf terbiasa tidak menggunakan alat keselamatan kerja saat bekerja.

\section{Analisis kebutuhan pelatihan subdivisi maintenance}

Analisis nilai KKJ dan KKP untuk supervisor divisi maintenance terdapat tiga deskripsi tugas yang membutuhkan pelatihan dengan gap KKJKKP $>1$. Hasil olah diagram PKP untuk semua deskripsi tugas membutuhkan pelatihan menunjukkan letak titik potong semua deskripsi tugas berada pada bidang B yang artinya karyawan membutuhkan pelatihan tetapi tidak dalam kondisi mendesak.

Prioritas pertama pelatihan yang dibutuhkan untuk supervisor subdivisi maintenance adalah kemampuan menyampaikan kebijakan yang disampaikan oleh jabatan di atasnya kepada seluruh staf. Hal ini sangat berkaitan erat dengan metode komunikasi efektif antara supervisor dengan staf. Prioritas selanjutnya yaitu deskripsi tugas berdasarkan kompetensi bidang pekerjaan yang harus dikuasai yaitu menyiapkan rencana pengontrolan harian pada lini produksi. Prioritas terakhir adalah penyusunan program pelatihan terkait dengan keselamatan kerja karyawan.

Hasil analisis nilai KKJ dan KKP untuk staff divisi workshop terdapat empat deskripsi tugas yang membutuhkan pelatihan. Hasil olah diagram PKP menunjukkan titik potong berada pada bidang $\mathrm{B}$, artinya keenam deskripsi pekerjaan tersebut membutuhkan pelatihan namun tidak dalam kondisi mendesak.

Kompetensi bidang pekerjaan membutuhkan pelatihan berdasarkan prioritas, yaitu merekomendasikan tindakan penanggulangan pada keabnormalan mesin dan peralatan sebagai salah satu tugas utama staff maintenance. Berdasarkan hasil olah KKJ dan KKP, maka pekerjaan ini perlu dilakukan pelatihan. Staff maintenance mampu memperbaiki keabnormalan alat dan mesin untuk kegiatan produksi namun sebagian darinya merasa takut dan tidak percaya diri untuk merekomendasikan tindakan penanggulangan keabnormalan mesin.

\section{Analisis kebutuhan pelatihan subdivisi QC}

Hasil analisis nilai KKJ dan KKP untuk supervisor divisi QC terdapat tujuh deskripsi tugas yang membutuhkan pelatihan dengan gap KKJKKP $>1$. Hasil olah diagram PKP untuk semua deskripsi tugas yang membutuhkan pelatihan yaitu letak titik potong semua deskripsi tugas berada pada bidang B yang artinya karyawan pada deskripsi pekerjaan tersebut membutuhkan pelatihan, tetapi tidak dalam kondisi mendesak.

Ketujuh deskripsi pekerjaan yang membutuhkan pelatihan terdapat pada bidang B diagram PKP, maka prioritas pelatihan yang dilakukan dinilai berdasarkan besaran gap setiap deskripsi pekerjaan. Kemampuan menjalankan keselamatan kerja setiap karyawan dinilai memiliki gap paling besar antara KKJ dan KKP, sehingga menjadi prioritas pertama pelatihan yang dibutuhkan

Prioritas kedua terkait dengan deskripsi pekerjaan pada kompetensi bidang pekerjaan, yaitu kemampuan memastikan produk dari standar perusahaan memenuhi mutu ISO, kemampuan menyampaikan kebijakan ke staff dan kemampuan berkomunikasi yang baik. Prioritas ketiga adalah deskripsi tugas pada kompetensi bidang pekerjaan yaitu kemampuan 
membuat rencana jangka pendek untuk tugas dari manajer, kemampuan menjaga checklist proses inspeksi dan protokol yang digunakan dalam suatu perusahaan, bertanggungjawab mengidentifikasi masalah dan isu mengenai mutu produk.

Hasil analisis nilai KKJ dan KKP untuk staf divisi workshop terdapat lima deskripsi tugas yang membutuhkan pelatihan. Hasil olah diagram PKP menunjukkan titik potong berada pada bidang B, artinya kelima deskripsi pekerjaan tersebut membutuhkan pelatihan, namun tidak dalam kondisi mendesak.

Pengetahuan tentang keselamatan kerja dalam melakukan pekerjaan sesuai dengan aturan perusahaan perlu ditingkatkan untuk kesadaran keamananan diri bagi staff QC. Penggunaan alat seperti cutter dan gunting dalam proses finishing produk, masker untuk menghindari kontaminasi bahan kimia karet buatan dalam kegiatan in coming. Deskripsi pekerjaan pada kompetensi intelektual yang harus dimiliki staff adalah memiliki sikap inisiatif dalam melaksanakan pekerjaan dan pada kompetensi emosional yaitu mengendalikan diri ketika menghadapi masalah masih perlu ditingkatkan melalui program pelatihan yang sesuai. Deskripsi pekerjaan pada kompetensi sosial yang menjadi standar perusahaan dan harus dimiliki oleh setiap karyawan adalah kemampuan bertanggungjawab menyelesaikan pekerjaan sesuai dengan tugas pekerjaan dan melaksanakan pengawasan terhadap pelaksanaan tugas rekan kerja dinilai perlu ditingkatkan melalui pelatihan.

\section{Analisis Kebutuhan Pelatihan Subdivisi PPIC}

Hasil analisis nilai KKJ dan KKP untuk supervisor subdivisi PPIC terdapat dua deskripsi tugas yang membutuhkan pelatihan dengan gap KKJ-KKP >1. Hasil olah diagram PKP untuk semua deskripsi tugas yang membutuhkan pelatihan menunjukkan bahwa letak titik potong semua deskripsi tugas berada pada bidang B, yaitu karyawan PPIC berada pada kondisi membutuhkan pelatihan tetapi tidak mendesak.

Dua deskripsi tugas yang membutuhkan pelatihan berada pada standar kompetensi bidang pekerjaan yaitu membuat jadwal perencanaan dari kegiatan di bagian produksi berdasarkan permintaan dari bagian pemasaran dan berdasarkan kapasitas mesin dan tugas kedua, yaitu kemampuan mengendalikan stok dari bahan baku, kemasan, dan bahan jadi agar seuai dengan perencanaan produksi dan permintaaan dari pemasaran. Kedua deskripsi pekerjaan tersebut menjadi prioritas sama, karena hasil analisis diagram PKP terdapat pada bidang yang sama dan nilai gap KKJ dan KKP juga sama.

Hasil analisis nilai KKJ dan KKP untuk staff divisi PPIC terdapat tujuh deskripsi tugas yang membutuhkan pelatihan. Hasil olah diagram PKP menunjukkan bahwa titik potong berada pada bidang B, artinya kelima deskripsi pekerjaan tersebut membutuhkan pelatihan namun tidak dalam kondisi mendesak. Ketujuh deskripsi pekerjaan yang membutuhkan pelatihan merupakan Deskripsi tugas yang berada pada kompetensi intelektual, emosional dan sosial, yaitu kemampuan inisiaitif dalam melaksanakan pekerjaan, kedisiplinan dalam bekerja, mengendalikan diri ketika menghadapi masalah, memotivasi rekan kerja, atasan, bawahan, melaksanakan kerjasama dengan anggota maupun rekan kerja dan model komunikasi efektif, serta pengetahuan terhadap keselamatan kerja.

\section{Perancangan program pelatihan}

Dari hasil analisis kebutuhan pelatihan dengan sistem penilaian kemampuan kerja masing-masing individu karyawan maka dapat diidentifikasi kompetensi yang memerlukan pelatihan dan juga prioritas pelatihan bagi karyawan (Singh, 2014).

Setelah dilakukan analisis kebutuhan pelatihan, yaitu merancang program pelatihan yang dibutuhkan dengan mengelompokkan deskripsi-deskripsi tugas yang membutuhkan pelatihan tersebut ke dalam kelompok kompetensinya, sehingga diketahui jenis kompetensi yang perlu ditingkatkan. Jenis pelatihan berdasarkan kompetensi yang membutuhkan pelatihan untuk tiap sub divisi dapat dilihat pada Tabel 7. 
Tabel 7. Jenis pelatihan berdasarkan kompetensi yang memerlukan pelatihan

\begin{tabular}{|c|c|c|c|}
\hline Kompetensi & Deskripsi tugas & Peserta pelatihan & Jenis pelatihan \\
\hline \multirow{4}{*}{$\begin{array}{l}\text { Kompetensi } \\
\text { intelektual }\end{array}$} & $\begin{array}{l}\text { Menganalisis masalah dan memberikan } \\
\text { alternatif pemecahannya }\end{array}$ & Manajer divisi workshop & $\begin{array}{l}\text { Pelatihan problem solving } \\
\text { and decision making }\end{array}$ \\
\hline & $\begin{array}{l}\text { Mengambil keputusan dalam kondisi } \\
\text { yang kritis dengan tepat }\end{array}$ & Manajer divisi workshop & $\begin{array}{l}\text { Pelatihan problem solving } \\
\text { and decision making }\end{array}$ \\
\hline & $\begin{array}{l}\text { Menguasai informasi mengenai } \\
\text { pekerjaan yang akan dilakukan }\end{array}$ & Staf maintenance & $\begin{array}{l}\text { Pelatihan pengenalan } \\
\text { SOP Perusahaan }\end{array}$ \\
\hline & $\begin{array}{l}\text { Memiliki sikap inisiatif dalam } \\
\text { melaksanakan pekerjaan }\end{array}$ & Staf QC, Supervisor ppic & $\begin{array}{l}\text { Outbond, creativity } \\
\text { training }\end{array}$ \\
\hline \multirow{3}{*}{$\begin{array}{l}\text { Kompetensi } \\
\text { emosional }\end{array}$} & Kedisiplinan dalam bekerja & Staf PPIC & $\begin{array}{l}\text { Personal development } \\
\text { training }\end{array}$ \\
\hline & $\begin{array}{l}\text { Mengendalikan diri ketika menghadapi } \\
\text { masalah }\end{array}$ & $\begin{array}{l}\text { Manajer divisi Workshop, } \\
\text { Staf QC, Supervisor PPIC }\end{array}$ & $\begin{array}{l}\text { Personal development } \\
\text { training }\end{array}$ \\
\hline & $\begin{array}{l}\text { Bertanggungjawab menyelesaikan } \\
\text { pekerjaan sesuai dengan tugas pekerjaan }\end{array}$ & Staf produksi, Staf QC & $\begin{array}{l}\text { Personal development } \\
\text { training }\end{array}$ \\
\hline \multirow{6}{*}{$\begin{array}{l}\text { Kompetensi } \\
\text { sosial }\end{array}$} & $\begin{array}{l}\text { Memotivasi rekan kerja, atasan dan } \\
\text { bawahan }\end{array}$ & Supervisor PPIC & Team building training \\
\hline & $\begin{array}{l}\text { Melaksanakan kerjasama dengan } \\
\text { anggota maupun rekan kerja }\end{array}$ & Supervisor PPIC & Team building training \\
\hline & $\begin{array}{l}\text { Mengembangkan komunikasi yang baik } \\
\text { dengan rekan kerja }\end{array}$ & $\begin{array}{l}\text { Staf produksi, Staf } \\
\text { maintenance, Supervisor } Q C \text {, } \\
\text { Staf PPIC }\end{array}$ & $\begin{array}{l}\text { Communication skill } \\
\text { training }\end{array}$ \\
\hline & $\begin{array}{l}\text { Melaksanakan pengawasan terhadap } \\
\text { pelaksanaan tugas rekan kerja }\end{array}$ & Supervisor produksi & Team building training \\
\hline & Membimbing rekan kerja & Staff produksi & Team building training \\
\hline & $\begin{array}{l}\text { Menyampaikan kebijakan yang } \\
\text { disampaikan oleh jabatan di atasnya } \\
\text { kepada seluruh staf }\end{array}$ & $\begin{array}{l}\text { Supervisor maintenance, } \\
\text { Supervisor QC }\end{array}$ & $\begin{array}{l}\text { Communication skill } \\
\text { training }\end{array}$ \\
\hline \multirow{10}{*}{$\begin{array}{l}\text { Kompetensi } \\
\text { bidang } \\
\text { pekerjaan }\end{array}$} & $\begin{array}{l}\text { Menyusun rencana kerja dan anggaran } \\
\text { tahunan pada divisi }\end{array}$ & Manajer divisi workshop & $\begin{array}{l}\text { Management project } \\
\text { training }\end{array}$ \\
\hline & $\begin{array}{l}\text { Membuat rencana jangka pendek untuk } \\
\text { tugas yang telah ditetapkan manajer }\end{array}$ & $\begin{array}{l}\text { Supervisor sub divisi } \\
\text { produksi, Supervisor } \\
\text { maintenance, }\end{array}$ & $\begin{array}{l}\text { Pelatihan penyusunan } \\
\text { bisnis anggaran }\end{array}$ \\
\hline & $\begin{array}{l}\text { Menyelesaikan pelaksanaan setiap } \\
\text { tahapan dalam proses produksi }\end{array}$ & Staf produksi & $\begin{array}{l}\text { Personal development } \\
\text { training }\end{array}$ \\
\hline & $\begin{array}{l}\text { Merekomendasikan tindakan } \\
\text { penanggulangan pada keabnormalan } \\
\text { mesin dan peralatan }\end{array}$ & Staf maintenance & $\begin{array}{l}\text { Competitive maintenance } \\
\text { and spare part management }\end{array}$ \\
\hline & $\begin{array}{l}\text { Menjalankan mesin/alat produksi sesuai } \\
\text { dengan prosedur yang benar }\end{array}$ & $\begin{array}{l}\text { Staf produksi, Staff } \\
\text { maintenance }\end{array}$ & Pemahaman SOP \\
\hline & $\begin{array}{l}\text { Melakukan evaluasi dan pelaporan tiap } \\
\text { program kerja yang telah dilaksanakan }\end{array}$ & Manajer divisi workshop & Management leadership \\
\hline & $\begin{array}{l}\text { Bertanggungjawab terhadap proses } \\
\text { produksi di perusahaan terkait dengan } \\
\text { penggunaan teknologi untuk kegiatan } \\
\text { produksi }\end{array}$ & Manajer divisi workshop & Management leadership \\
\hline & $\begin{array}{l}\text { Membuat jadwal perencanaan dari } \\
\text { kegiatan di bagian produksi berdasarkan } \\
\text { permintaan dari bagian pemasaran dan } \\
\text { berdasarkan kapasitas mesin }\end{array}$ & Supervisor PPIC & PPIC training \\
\hline & $\begin{array}{l}\text { Menyiapkan rencana pengontrolan } \\
\text { harian pada lini produksi }\end{array}$ & Supervisor maintenance & $\begin{array}{l}\text { Training maintenance } \\
\text { management }\end{array}$ \\
\hline & Menyusun rencana produksi mingguan & $\begin{array}{l}\text { Supervisor subdivisi } \\
\text { produksi }\end{array}$ & Production officer program \\
\hline
\end{tabular}




\begin{tabular}{|c|c|c|c|}
\hline Kompetensi & Deskripsi tugas & Peserta pelatihan & Jenis pelatihan \\
\hline & $\begin{array}{l}\text { Menjalankan keselamatan kerja dalam } \\
\text { melakukan pekerjaan sesuai dengan } \\
\text { aturan perusahaan }\end{array}$ & $\begin{array}{l}\text { Supervisor produksi, staf } \\
\text { produksi, Supervisor } \\
\text { maintenance, Staf } \\
\text { maintenance, Staf } Q C, \text { Staf } \\
\text { PPIC }\end{array}$ & Pelatihan SMK3 \\
\hline & $\begin{array}{l}\text { Mengendalikan stok dari bahan baku, } \\
\text { kemasan, dan bahan jadi agar sesuai } \\
\text { perencanaan produksi dan permintaaan } \\
\text { dari pemasaran }\end{array}$ & Supervisor PPIC & Pelatihan PPIC \\
\hline & $\begin{array}{l}\text { Memastikan produk dari standar } \\
\text { perusahaan memenuhi mutu ISO }\end{array}$ & Supervisor QC, & Pelatihan QC dan QA \\
\hline & $\begin{array}{l}\text { Menjaga checklist proses inspeksi dan dan } \\
\text { protokol yang digunakan dalam suatu } \\
\text { perusahaan }\end{array}$ & Supervisor QC, & Pelatihan QC dan QA \\
\hline & $\begin{array}{l}\text { Bertanggungjawab mengidentifikasi } \\
\text { masalah dan isu mengenai kualitas } \\
\text { produk }\end{array}$ & Supervisor QC, & Pelatihan QC dan QA \\
\hline & $\begin{array}{l}\text { Penjadwalan jangka pendek dan } \\
\text { menengah }\end{array}$ & Manajer divisi workshop & $\begin{array}{l}\text { Pelatihan manajemen } \\
\text { proyek }\end{array}$ \\
\hline & $\begin{array}{l}\text { Mengembangkan staf sesuai dengan } \\
\text { bidang pekerjaan yang sesuai }\end{array}$ & Manajer divisi workshop & Management leadership \\
\hline & $\begin{array}{l}\text { Bertanggungjawab terhadap keselamatan } \\
\text { kerja karyawan }\end{array}$ & Manajer divisi workshop & Management leadership \\
\hline & $\begin{array}{l}\text { Bertanggungjawab terhadap kesesuaian } \\
\text { pekerjaan dengan kinerja staf di sub } \\
\text { divisi PPIC, Production, Quality Control, } \\
\text { Maintenance dan Engineering }\end{array}$ & Manajer divisi workshop & Management leadership \\
\hline
\end{tabular}

\section{KESIMPULAN}

Persepsi karyawan perusahaan OBK terhadap pelatihan yang pernah diikuti berbeda dengan karyawan yang tugasnya berhubungan dengan produksi (Subdivisi produksi dan subdivisi PPIC) dengan karyawan yang tugasnya di luar produksi (Subdivisi maintenance dan quality control).

Semakin puas karyawan terhadap pelatihan, maka semakin puas pula pada peningkatan kinerjanya. Hal ini berlaku pada semua subdivisi kecuali subdivisi maintenance.

Penyusunan kebutuhan pelatihan sesuai dengan kondisi karyawan ditemukan pada kompetensi intelektual, yaitu pelatihan mengenai analisis masalah dan membuat keputusan, pelatihan pengenalan SOP dan pelatihan peningkatan kemampuan inisiatif. Pada kompetensi emosional, yaitu pelatihan pengembangan diri. Pada kompetensi sosial, yaitu pelatihan membangun sebuah tim dan pelatihan komunikasi. Pada kompetensi bidang pekerjaan untuk manajer, yaitu management project training dan kepemimpinan. Pada subdivisi produksi yaitu production officer program dan pelatihan K3, sub divisi maintenance yaitu competitive maintenance and spare part management dan pelatihan K3. Pada subdivisi QC, yaitu quality control and quality assurance training, subdivisi PPIC, yaitu Pelatihan production, planning, inventory control.

\section{DAFTAR PUSTAKA}

Ajani, T, Stork E. 2013. Creating semantic differential scale for measuring user's perception and attitude toward emerging technologies. Proceedings of the Conference for Information Systems Applied Research. ISSN: 2167-1508. San Antonio, Texas.

[BCG] Boston Consulting Group. 2013. Tackling Indonesia's talent challenges: Growing pains lasting advantage [Internet]. Diakses dari http://www

bcg.com/expertise.impact/publications $\quad[20$ Maret 2015]

Dahiya S, Jha A. 2011. Training needs assessment: critical study.International Journal of Information Technology and Knowledge Management. 4(1): 263 - 267.

Elnaga, Amir., Imran, Amen,. 2013. The Effect of Training on Employee Performance. European Journal of Business and Management. 5(4):137-147. 
Fokno, E.D., Boakye, J.K., Kwaning, C.O. 2014. Training And Development: A Tool For Employee Performance In The District Assembles In Ghana. International Journal of Education and Research. 2(5):27-3.

Hameed A, Abdul W. 2011. Employee development and its affect on employee performance a conceptual framework. International Journal of Business and Social Science. 2(13):224-229.

Khan, R.A.G., Khan, F.A., Khan, M.A. 2011. Impact of Training and Development on Organizational Performance. Global Journal of Management and Business Research. Vol.11 Issue 7

Lee, G. J. 2015. Training match and mismatch as a driver of key employee beha-viours. Human Resource Management Journal, 25: 478-495.

McClelland, Susan D. 2002. A Training Needs Assessment for the united way of dunn county wiwcounsin [Thesis]. Amerika Serikat (AS): University of Wisconsin-Stout.
Pizam A, Valeriya S, Taylor E. 2016. Customer satisfaction and its measure-ment in hospitality enterprises: a revisit and update", International Journal of Contemporary Hospitality Management, Vol. 28 Iss: 1, pp. $2-35$.

Santoso S. 2012. Panduan Lengkap SPSS. Jakarta (ID): Elex Media Komputindo

Sanusi A. 2011. Metodologi Penelitian Bisnis. Jakarta (ID): Salemba Empat

Sedarmayanti, Syarifuddin H. 2002. Metode Penelitian. Bandung (ID): mandar maju

Sekaran U, Bougie R. 2010. Research Methods for Business. Ed ke-5. United Kingdom (GB):Wiley

Singh D. 2014. Employee survey on performance appraisal system (a case study of BHEL: HERP Varanasi). Indian Journal of Applied Research. 4(6):83-85

Tashima J, McCan T. 1994. Training Needs Assessment Tools. King of Prussia, Pa.: HRDQ. 